\title{
The Assessment and Management of Amandit Sub-watershed Sustainability, South Kalimantan
}

\author{
Ferry Juniansyah $^{1}$, Imam Hanafi ${ }^{2}$ and Kliwon Hidayat ${ }^{3}$ \\ ${ }^{I}$ Graduate School of Environmental Science Brawijaya University, Malang East Java and Public Work \\ Department of Hulu Sungai Tengah Regency, Barabai South Kalimantan, Indonesia \\ ${ }^{2}$ Faculty of Administrative Science Brawijaya University, Malang East Java \\ ${ }^{3}$ Faculty of Agriculture, Brawijaya University, Malang East Java
}

\begin{abstract}
The aim of the research is to evaluate the contribution of environmental, economical, social, institutional and technological dimension in the sustainability of Amandit sub-watershed area in South Kalimantan. The sustainability aspect was assed using Multi-dimensional Scaling (MDS) methods using RapSubDAS-AMANDIT approach. Result of the study shows that in the upstream area, the sustainability of environmental dimension can be classified as moderate. (57.37), the sustainability of economic dimension as moderate (57.19), the sustainability of social dimension as poor (45.79), the sustainability of technological dimension as poor (26.67), and the sustainability of institution dimensions as poor (35.43). In the middle area the sustainability of environmental dimension can be classified as poor (45.44), the sustainability of economic dimension as moderate (66.62), the sustainability of social dimension as moderate (57.37), the sustainability of technological dimension as poor (42.86), and the sustainability of institution dimensions as poor (39.00). In the downstream area, the sustainability of environmental dimension can be classified as poor (44.40), the sustainability of economic dimension as moderate (55.20), the sustainability of social dimension as moderate (53.15), the sustainability of technological dimension is poor (45.17), and the sustainability of institution dimensions is poor (37.47). The holistic management approach of Amandit sub-watershed area therefore important.
\end{abstract}

Keywords: sustainable development, watershed management, Kalimantan, environmental conservation

\section{Introduction}

Watershed management recently received an intensive attention and discussion among scholars. For numerous communities in the world, particularly people who lived in watershed area, ecological process inside watershed area are becoming a major part of their live. The health of watershed will affect the human prosperity. According to numerous studies, watershed thought out the world facings serious threats which lead to its sustainability. Unsustainable used of lands and natural resources in watershed area lead to the numerous negative impact which decrease the productivity of lands, quality of water and other environmental services [1] [2] [3] [4].

Technically, a watershed can be defined as area of land in which all of the water that falls in it and drains off of it to go to a common outlet as a stream. In term of size, watersheds can be delineated on a small scale or on a macro-scale. In watershed, the area numerous element which has been identified influence the watershed quality and health. Scholars point out that the health of the upland areas of a watershed will contributes significantly to the quantity and quality of the water downstream area. The conservation of upland is therefore important for watershed management [4] [5].

Recently, the issues of sustainable development emerging as part of the global strategy to ensure the sustainable live in biosphere. Scholar point out that sustainable development principle was relevant with recent global growth, where industrial grows rapidly but environmental degradation grows fast. There are numerous environmental degradation has been reported, ranging from pollution to habitat loss. Environmental degradation which was caused by recent development has negative impact to global human live, and therefore new approach and strategy for development was needed. Sustainable development recently becomes important concept of development. Scholar sand politician argues that there are at least three aspects should be accommodated in development, namely economic, environment and social. In the scenario of global sustainable development, this aspect should be accommodated in balance [6] [7] [8].

Watershed management and sustainable development is the main agendas for numerous global community. Watershed should be planned and managed following sustainable development principles. Beyond economic, social and environmental, the human technology and institution to utilize natural resources is important. Technology and institution has double sides impact, negative and positive. To the implementation of sustainable development, the technology should be addressed to increase sustainable practices of human 
utilization over resources [9]. There are also important to increase the capacity of institution to increase sustainability of resources utilization [10].

Kalimantan is home of global mega-biodiversity. The importance of Kalimantan's biodiversity for global life as been reported significant. Recent rapid development and natural resources exploitation ahs reported contributes to however, environmental degradation. The sustainability of watershed in Kalimantan area is in problems due to rapid development [11] [11]. Sub-watershed of Amandit is part of the Barito watershed in South Kalimantan, Indonesia. The aims of the research is to evaluate the contribution of environmental, economical, social, institutional and technological dimension in the sustainability of Amandit sub-watershed area in South Kalimantan.

\section{Study area}

\section{Methodology}

Amandit sub-watershed area spread from Meratus Highland to the Barito River Valley. Totally, the area of watershed was estimated about $117,921.26$ hectare or equal to $6.33 \%$ of the total area of Barito Watershed area. The length of Amandit sub-watershed area was about $98.973 \mathrm{~km}$. The erosion rate in Amandit watershed area was recorded about 15-60 tones/hectare/year. It can be classifies into class II erosion type. Many lands area are degraded and loss the ability to support crops and agricultural productivity. There are critical lands in Amandit sub-watershed. Forest degradation contributes significantly in watershed degradation. Recent critical land of Amandit watershed was given in Table 1.

Table 1. Critical lands distribution and status in Amandid sub-watershed rea in South Kalimantan, 2010

\begin{tabular}{|l|l|l|l|l|l|l|l|l|}
\hline \multirow{2}{*}{ Administration area } & \multicolumn{4}{|l|}{ Critical land category } & \multicolumn{2}{l|}{ Area } & \multicolumn{2}{l|}{ Critical lands } \\
\cline { 2 - 9 } & Good lands & $\begin{array}{l}\text { Potentially } \\
\text { critical lands }\end{array}$ & $\begin{array}{l}\text { Low } \\
\text { critical land }\end{array}$ & $\begin{array}{l}\text { Critical } \\
\text { lands }\end{array}$ & $\begin{array}{l}\text { Very critical } \\
\text { lands }\end{array}$ & & \\
\hline Tapin Regency & $1,272.9$ & $87,613.9$ & $101,816.9$ & $24,262.9$ & $4,576.4$ & $219,542.4$ & $28,839.1$ & $13.1 \%$ \\
\hline $\begin{array}{l}\text { Hulu Sungai Selatan } \\
\text { Regency }\end{array}$ & $5,045.1$ & $21,684.9$ & $112,003.2$ & $28,327.4$ & $2,323.0$ & $169,383.7$ & $30,650.4$ & $18.1 \%$ \\
\hline Total area & $6,318.0$ & $109,298.4$ & $213,820.1$ & $52,590.3$ & $6,899.2$ & $388,926.1$ & $59,489.5$ & $15.3 \%$ \\
\hline
\end{tabular}

Sources: Badan Pengelolaan Daerah Aliran Sungai (DAS) Barito [13].

Hulu Sungai Selatan Regency has highest critical lands (18.1\% of the total regency area), compared to the Tapin Regency (13.1\% of the total regency area). Totally, the critical lands of Amandit sub-watershed was estimated 59,489.5 hectares or equal to the $15.3 \%$ of sub watershed area (Fig. 1). Compared to the national critical lands standard for watershed critical area, Amandit sub-watershed area has highest proportion of critical land [14]. It means, the Amadit sub-watershed area need the comprehensive management.

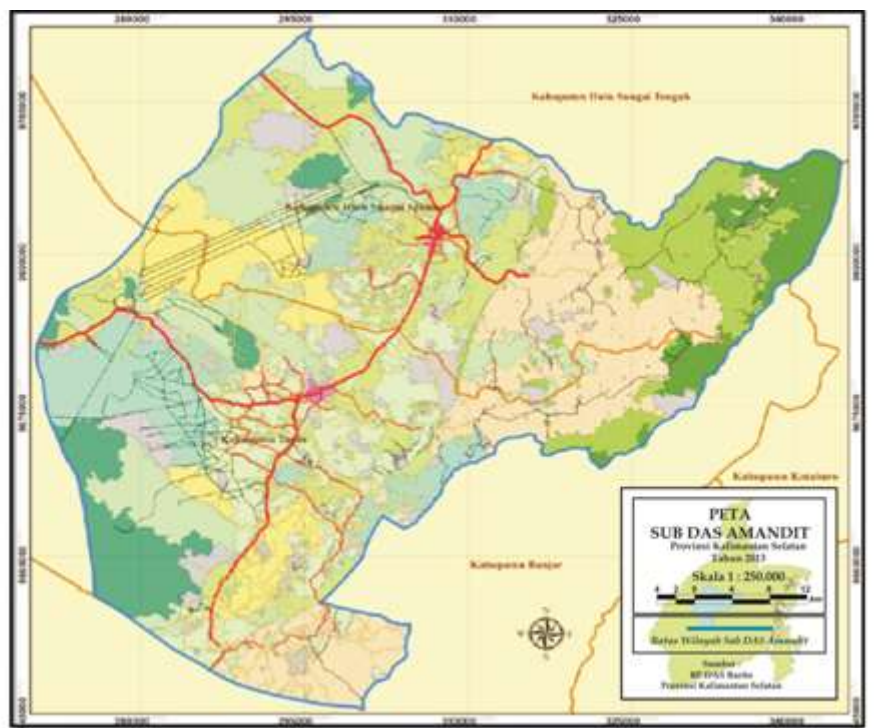

Fig.1. The Amadit sub-watershed area in South Kalimantan

\section{Methods}

The sustainability aspect of Amandit sub-watershed management was assed using Multi-dimensional Scaling (MDS) methods using RapSubDAS-AMANDIT approach. This approach was developed from modification of RAPFISH-Rapid Appraisal for Fisheries, one of the Multi-dimensional Scaling (MDS) which 
area developed by Fisheries Centre of the University of British Columbia. Five aspects which were related to the sustainability of Amandit sub-watershed were assessed, namely environmental, economical, social, technology and institution dimensions. The attributes of each dimension was set up to accommodated all of the possible aspect, in which theoretically and empirically contributes to the sub-watershed utilizations.

Sample was done through purposive sampling with common and specific criteria. The common criteria encompasses respondent expertise in their field while the specific aspect encompasses (a) experiences and competency according to field research themes, (b) has reputation position and shows its credibility as expert related to the research theme, (c) has commitment to the proposed problems of research, and (d) neutral and free from political interest, has acceptability of other comment and argument. From this criteria and consideration, this research use 25 questionnaire items which are distributes to 5 respondents.

\section{Data analysis}

Data was analyzing using Multidimensional Scaling (MDS) with Rapid Appraisal Sub DAS Amandit (RapSubDAS-AMANDIT). Analyses procedure was started from reviewing attributes and defining attributes. This is followed by scoring of attributes based on RAPFISH guidelines. Multidimensional Scaling (MDS) methods can be run following sequential methods, namely: (1) data from field survey was scored (2) in all measured character, the good and bad attributes was established (3) medium points was established. The medium point located at the centre of up and down point, (4) anchors point was established. It is especially important to identify ordination result analysis.

RAPFISH Ordination was established by dimensions that represent the sustainability of area development in every related aspect and presented in scales from 0 to $100 \%$. Sustainability point position can be drawn in both vertical and horizontal line, in which line shows the sustainability point from $0 \%$ (poor) to $100 \%$ (good). The sustainability point was achieved at value $>50$. Below $<50$ the dimension can be categorized as unsustainable. The stress value and determinant coefficient $\left(\mathrm{R}^{2}\right)$ determines whether additional attributes needed or not. It is especially important to show the accuracy and precision of observed dimensions. The stress value was allowed when value below 0.25 (this means the analysis was good). The classification on index value and its category was shown in Table 2. [15] [16].

Table 2.Index and sustainability status of Amandit sub-watershed in South Kalimantan Province

\begin{tabular}{|l|l|}
\hline Index value & Category \\
\hline $0-25$ & Poor (Not sustainable) \\
\hline $26-50$ & Less (Less sustainable) \\
\hline $51-75$ & Moderate \\
\hline $76-100$ & Good \\
\hline
\end{tabular}

Sources: Modified from Kavanagh and Pitcher (2004) [16].

\section{Leverage factor determination}

Leverage factor was calculated based on different standard error from score with attributes and scores without attributes. In the graph, leverage factor can be observed from the analysis' of Rapfish, especially from the highest value of root means square (RMS) to the medium value in each sustainability dimensions. Result of the leverage analysis will shows the percentage of root mean square of each attributes when deleted from ordination. Attribute with highest value represent the important attributes in sustainability [16].

\section{Monte Carlo Analysis}

Monte Carlo analysis was done in interval confidence 95\%. Comparison between Monte Carlo and MDS shows there are less different. This means impact of score addition was less, impact of variation of attributes was less, replication of MDS valuation was stable, and data mistake was relatively less. Comparing Monte Carlo and MDS results was done in interval confidence $95 \%$ to generate difference value more higher $(\mathrm{MC}-\mathrm{MDS}>5 \%)$ or less (MC - MDS < 5\%). If difference value of two analysis $>5 \%$ it means the MDS analysis not suitable as an index to predict sustainability, and if two value has $<5 \%$ it means MDS result able to used as an index to predict sustainability [16].

\section{Environmental sustainability status}

\section{Results and Discussions}

Environmental dimension in sustainability of Amandit sub-watershed management gives attention to the importance of caring capacity issues and management, encompasses lands, water, and area planning to ensue the sustainability uses of resources for future generation. There are 12 important attributes for sustainable uses of Amandit sub-watershed management, namely; critical lands, vegetation covers, erosion, lands slides, lands conservation, sediment loads, water flow, flood, water quality, water consumption, water conservation and biodiversity. The result of the assessment of RapSubDAS-AMANDIT was given in Fig.2. 

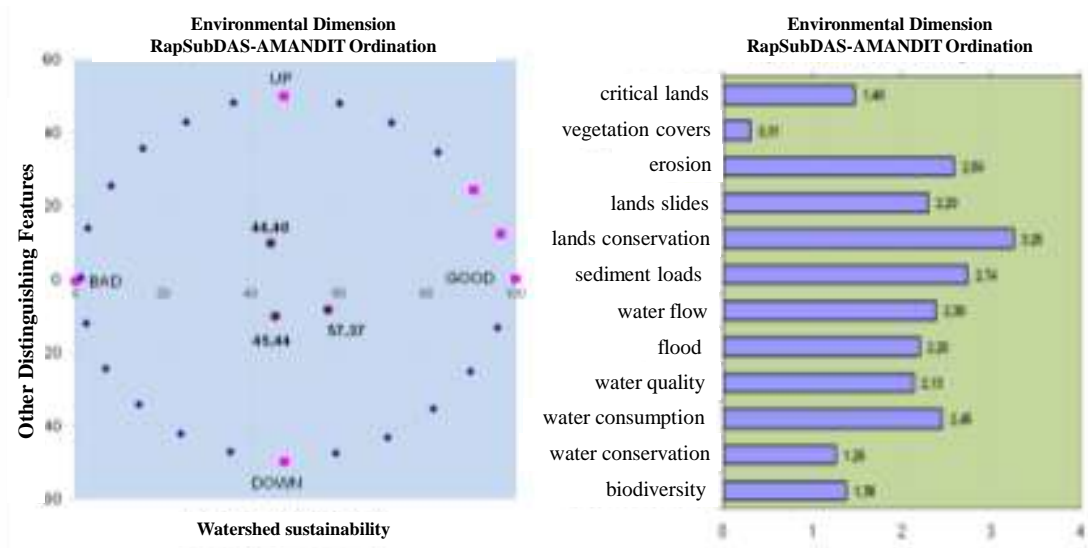

Fig. 2. Ordination sustainability and analysis laverage in environmental dimension of Amandit sub-watershed.

The ordination sustainability of environmental dimension in Amandit sub-watershed management and use as shown in Fig. 2 was drawn in Table 3.

Table 3.Index and status of sustainability of environmental dimension in integrated management of Amandit sub-watershed

\begin{tabular}{|c|c|c|c|c|c|}
\hline \multirow{2}{*}{$\begin{array}{l}\text { Area within Amandit } \\
\text { sub watershed }\end{array}$} & \multicolumn{2}{|c|}{ Sustainability } & \multirow[t]{2}{*}{$\mathrm{R}^{2}$} & \multicolumn{2}{|c|}{ Parameter } \\
\hline & Index & Sustainability status & & Stress & Decisions \\
\hline Upstream area & 57.37 & Moderates & \multirow[t]{3}{*}{$95.1 \%$} & \multirow[t]{3}{*}{$14.1 \%$} & \multirow{3}{*}{$\begin{array}{l}\text { Goodness } \\
\text { of fit }\end{array}$} \\
\hline Middle area & 45.44 & Less & & & \\
\hline Downstream area & 44.40 & Less & & & \\
\hline
\end{tabular}

Leverage analysis shows that there are several leveraging factors which provides sensitive impact to the environmental sustainability. This is including, land conservation (3.25); sediments loading (2.74); erosion (2.59); water utilization (2.45); water flow (2.38); and land slide (2.29). An improvement of these attributes was needed with the objectives is increasing environmental sustainability in Amandit sub-watershed in integrated perspectives. The issues of land conservation in watershed management are important. Scholars point out that unsustainable practice of agriculture and forest exploitation contributes to land degradation, including sedimentation. The issues of water and lands utilization are, therefore important. In Amandit sub watershed, it is especially important o increase watershed sustainability [17] [18].

\section{Economical Sustainability Status}

Economical dimension in sustainability of Amandit sub-watershed management gives attention to the improvement of human wellbeing and poverty eradication of community in watershed area. There are eight attributes which area related to economic sustainability, namely contribution to family income, contribution to local economic, Labor Force Absorption, land productivity, agriculture commodity prospect, protected area utilization, agricultural land utilization, and environmental services. The result of the assessment of RapSubDAS-AMANDIT was given in Fig.3.
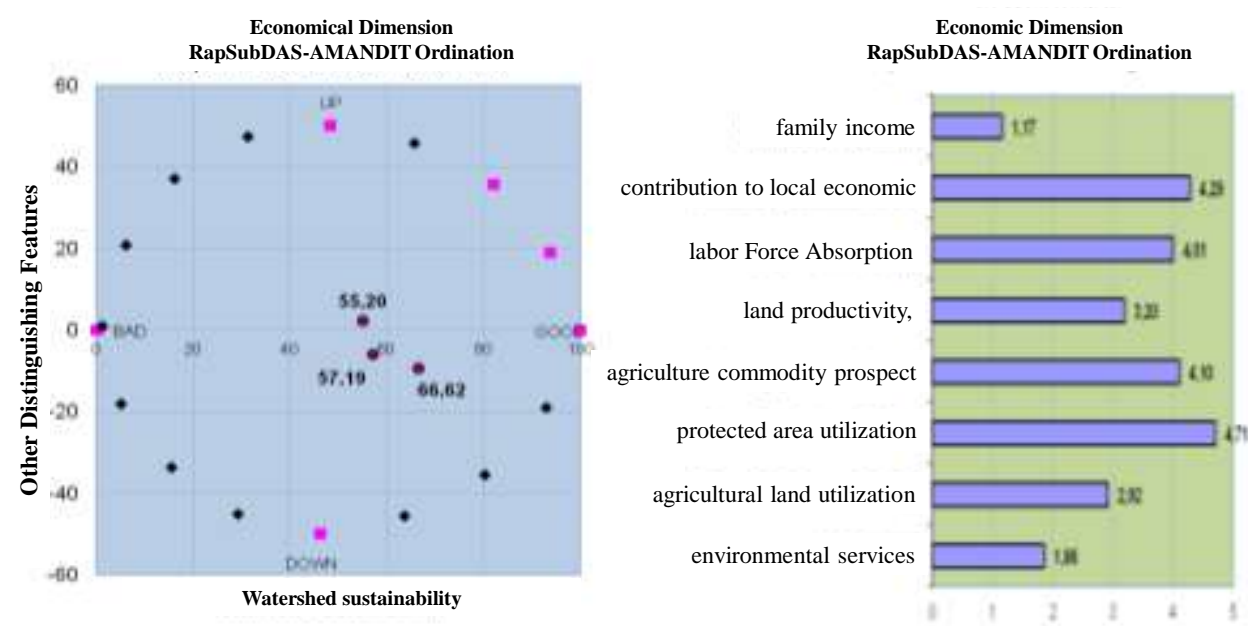
Fig. 3. Ordination sustainability and analysis of leverage in economical dimension of Amandit sub-watershed The ordination sustainability of economic dimension in Amandit sub-watershed management and use as shown in Fig. 3 was drawn in Table 4.

Table 4. Index and status of sustainability of economical dimension in integrated management of Amandit sub-watershed

\begin{tabular}{|l|l|l|l|l|l|}
\hline \multirow{2}{*}{$\begin{array}{l}\text { Area within Amandit } \\
\text { sub watershed }\end{array}$} & \multicolumn{2}{|l|}{ Sustainability } & \multirow{2}{*}{$\mathrm{R}^{2}$} & \multicolumn{2}{|l|}{ Parameter } \\
\cline { 2 - 3 } & Index & Sustainability status & & Stress & Decisions \\
\hline Upstream area & 57.19 & Moderates & \multirow{2}{*}{$94.6 \%$} & $14.1 \%$ & Goodness of fit \\
\hline Middle area & 66.62 & Moderates & & & \\
\hline Downstream area & 55.20 & Moderates & & & \\
\hline
\end{tabular}

Leverage analysis shows that there are several leveraging factors which provides sensitive impact to the environmental sustainability. This is including, utilization of protected area (4.71); contribution to local economic, (4.29); agriculture commodity prospect (4.10); and labor force absorption (4.01). Economic aspect contributes significantly in land degradation, especially when economic activity done without following ecological principles. In Amandit sub-watershed, there need improvement in economic activity with the objectives is increasing sustainability of sub watershed area [7] [17].

\section{Social Sustainability Status}

Social dimensions has close 1 relationship with human being. There social interaction within daily life of community. Social dimension in sustainability of Amandit sub-watershed management gives attention to the improvement of social aspect of community within watershed area. There are ten attributes which area related to social sustainability, namely 1) population pressure, 2) lands ownership status, 3) education levels of community, 4) environmental awareness, 5) public participation, 6) role of governments, 7) role of community informal leader, 8) role of private sectors, 9) safety, and 10) natural resources utilization conflict. The result of the assessment of RapSubDAS-AMANDIT was given in Fig.4.
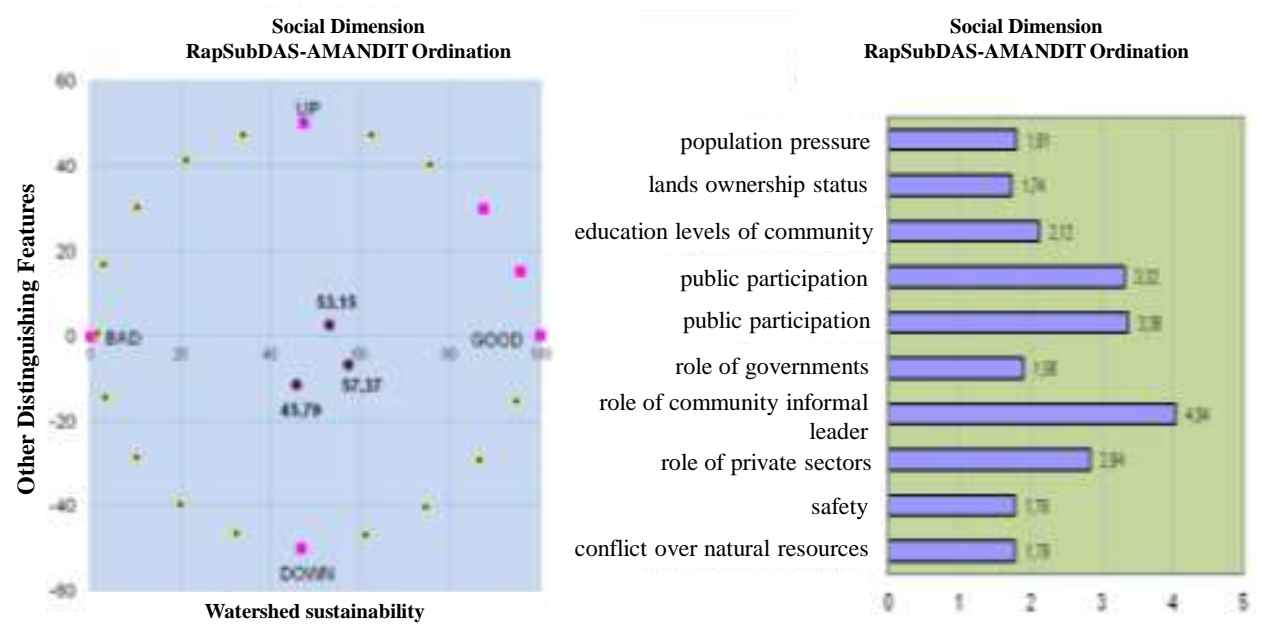

Fig. 4. Ordination sustainability and analysis of leverage in social dimension of Amandit sub-watershed

The ordination sustainability of social dimension in Amandit sub-watershed management and use as shown in Fig. 4 was drawn in Table 5.

Table 5.Index and status of sustainability of social dimension in integrated management of Amandit sub-watershed

\begin{tabular}{|l|l|l|l|l|l|}
\hline \multirow{2}{*}{$\begin{array}{l}\text { Area within Amandit } \\
\text { sub watershed }\end{array}$} & \multicolumn{2}{|l|}{ Sustainability } & $\mathrm{R}^{2}$ & \multicolumn{2}{|l|}{ Parameter } \\
\cline { 2 - 3 } & Index & Sustainability status & & Stress & Decision \\
\hline Upstream area & 45.79 & Moderates & \multirow{2}{*}{$94.7 \%$} & $14.3 \%$ & Goodness of fit \\
\hline Middle area & 57.37 & Moderates & & & \\
\hline Downstream area & 53.15 & Moderates & & & \\
\hline
\end{tabular}

Leverage analysis shows that there are several leveraging factors which provides sensitive impact to the social sustainability. This is including, the role of governments (4.04); public participation (3.38); environmental awareness (3.32); role of privates sector (2.84); and levels of education (2.12). Social sustainability has been discussed by numerous authors and conclude that the social aspect is important in 
sustainable development [6] [8] [9]. In Amandit sub watershed area, the programs of social well being improvement was needed. There are strategic issues should be addressed, including education.

\section{Technological Sustainability Status}

Technological dimensions for the sustainability of Amandit sub-watershed management has correlation with the utilization technology, especially simple and accessible technology, and accurate information technology to support management. Technological dimensions includes agricultural technology, fisheries technology, irrigation technology, post harvesting technology, facility and infrastructure, transportation access, information access, and conservation and rehabilitation technology. The result of the assessment of RapSubDAS-AMANDIT was given in Fig.5.
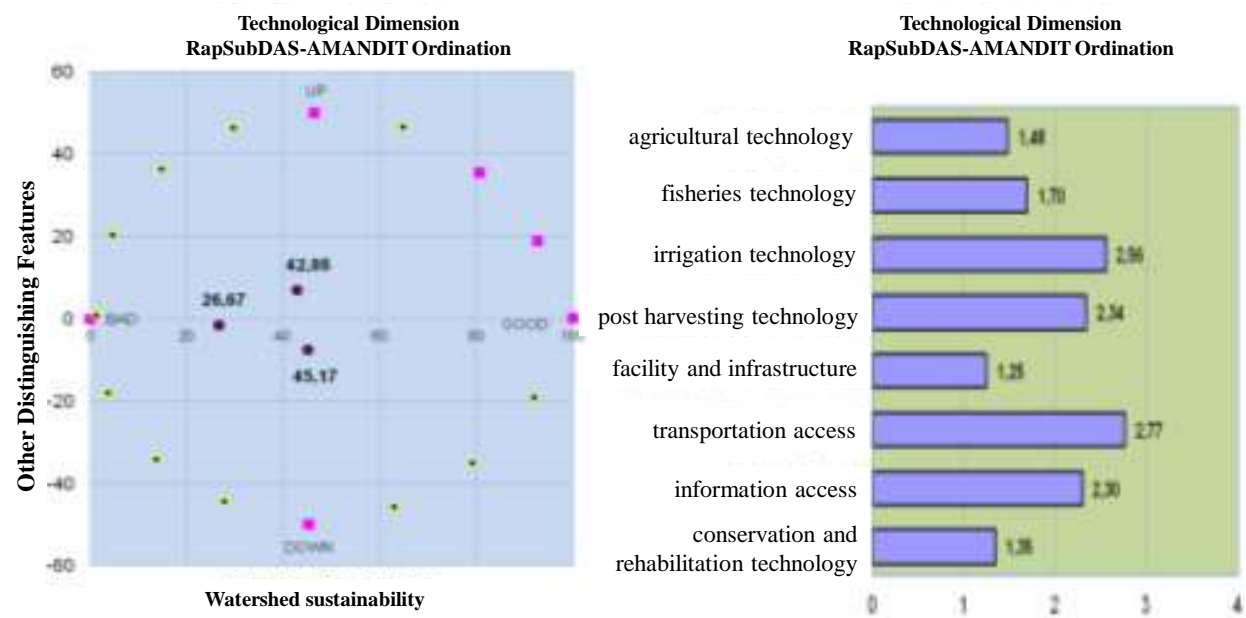

Fig. 5. Ordination sustainability and analysis of leverage in technology dimension of Amandit sub-watershed

The ordination sustainability of technological dimension in Amandit sub-watershed management and use as shown in Fig. 5 was drawn in Table 6.

Table 6.Index and status of sustainability of technological dimension in integrated management of Amandit sub-watershed

\begin{tabular}{|c|c|c|c|c|c|}
\hline \multirow{2}{*}{$\begin{array}{l}\text { Area within Amandit } \\
\text { sub watershed }\end{array}$} & \multicolumn{2}{|c|}{ Sustainability } & \multirow[t]{2}{*}{$\mathrm{R}^{2}$} & \multicolumn{2}{|c|}{ Parameter } \\
\hline & Index & Sustainability status & & Stress & Decision \\
\hline Upstream area & 26.67 & Less & \multirow[t]{3}{*}{$95.7 \%$} & \multirow[t]{3}{*}{$13.1 \%$} & \multirow{3}{*}{$\begin{array}{l}\text { Goodness } \\
\text { of fit }\end{array}$} \\
\hline Middle area & 42.86 & Less & & & \\
\hline Downstream area & 45.17 & Less & & & \\
\hline
\end{tabular}

Leverage analysis shows that there are several technological leveraging factors which provides sensitive impact to the sustainability. This is including, transportation access (2.77); irrigation technology (2.56); post harvesting technology (2.34); and information access (2.30). Transportation, irrigation and harvesting technology is important component for human daily life. Irrigation and post harvesting technology is important to increase crop productivity. This aspect has close relationship with the sustainability issues, especially among farmer in developing countries. Poor irrigation facility and post harvesting techniques lead to the low productivity. This is become the crucial key for poverty issues in developing countries [20].

\section{Institutional Sustainability Status}

Institutional dimension plays an important role in sustainability. Institution dimension related to the regulation and its related institutions. There are ten attributes related to the institution, namely regulation implementation, local institution empowerment, zonation of protected and farmlands area, intensity of Lawlessness, incentive and disincentive systems, KISS multi-sector, institution for communal business, instructor institution, research institutes, and cooperative institutions. The result of the assessment of RapSubDAS-AMANDIT was given in Fig.6. 

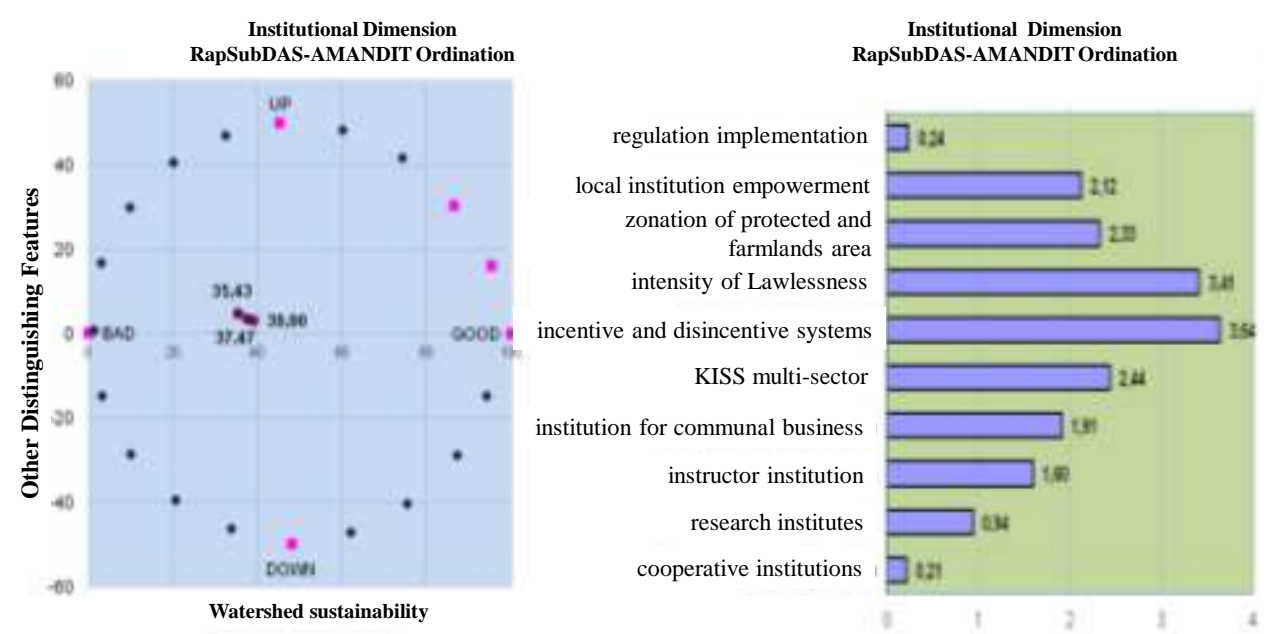

Fig. 6. Ordination sustainability and analysis of leverage in institutions dimension of Amandit sub-watershed

The ordination sustainability of institutions dimension in Amandit sub-watershed management and use as shown in Fig. 6 was drawn in Table 7.

Table 7.Index and status of sustainability of institutional dimension in integrated management of Amandit sub-watershed

\begin{tabular}{|l|l|l|l|l|l|}
\hline \multirow{2}{*}{$\begin{array}{l}\text { Area within Amandit } \\
\text { sub watershed }\end{array}$} & \multicolumn{2}{|l|}{ Sustainability } & \multicolumn{2}{l|}{ Parameter } \\
\cline { 2 - 3 } & Index & Sustainability status & & Stress & Decision \\
\hline Upstream area & 35.43 & Less & & \\
\hline Middle area & 39.00 & Less & & & \\
\hline Downstream area & 37.47 & Less & & Goodness of fit \\
\hline
\end{tabular}

Leverage analysis shows that there are several institutional leveraging factors which provides sensitive impact to the sustainability. This is including, incentive and disincentive systems (3.64); intensity of Lawlessness (3.41); KISS multi-sector (2.44); zonation of protected area and farmlands (2.33); and local institution empowerment (2.12). Involving local community to improve institutional dimension was important. It has been shows by the sustainability of home gardens as one of the important sites for biodiversity conservation in central Kalimantan, in which the contribution of local people involvement is important [21]

\section{Multidimensional sustainability status}

The measurements of Multidimensional sustainability status was done through integration all of the attributes of sustainability, namely environment, social, economy, institution and technology. The analysis multidimensional sustainability indices and status with forty eight attributes was given in Fig. 7.
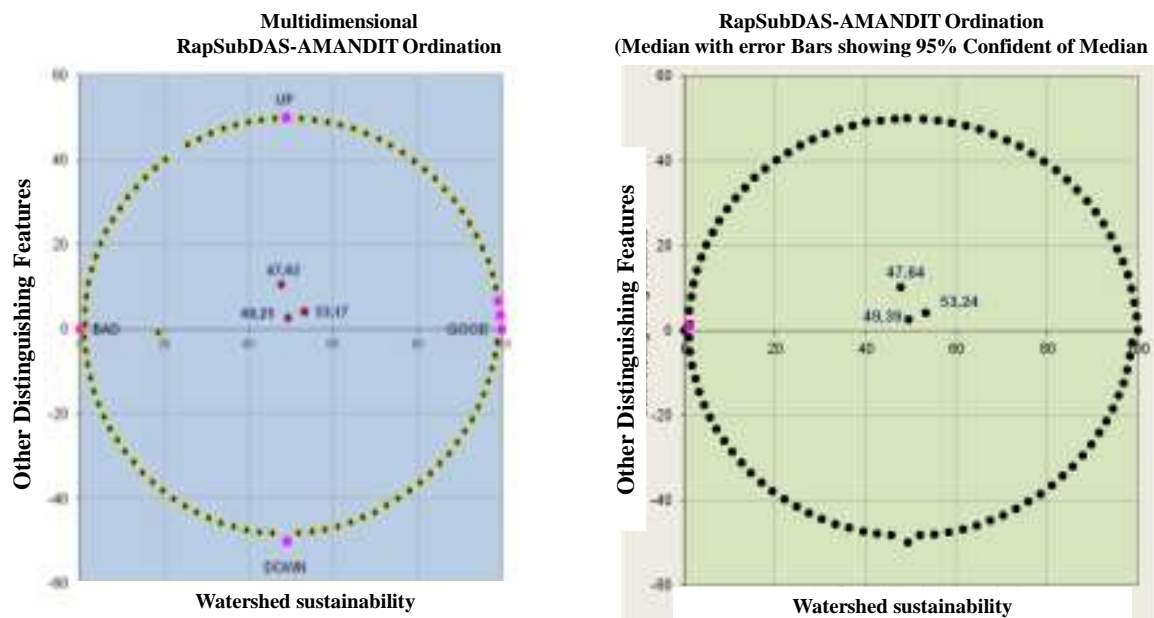

Fig. 7. Ordination of sustainability of MDS and Monte Carlo analysis using RapSubDAS-AMANDIT approach 
The index and status for multidimensional sustainability management in Amandit sub-watershed in South Kalimantan was given in Fig. 7 and Table 8.

Table 8.The index and status for multidimensional sustainability management in Amandit sub-watershed

\begin{tabular}{|l|l|l|l|l|l|}
\hline \multirow{2}{*}{$\begin{array}{l}\text { Area within Amandit } \\
\text { sub watershed }\end{array}$} & \multicolumn{3}{|l|}{$\mathrm{R}^{2}$} & & Sustainability \\
\cline { 2 - 3 } & Index & Sustainability status & & Stress & Decision \\
\hline Upstream area & 47.62 & Less & & $13.1 \%$ & Goodness of fit \\
\hline Middle area & 53.17 & Moderates & & \\
\hline Downstream area & 49.24 & Less & & \\
\hline
\end{tabular}

Determinant coefficient value shows that multidimensional analysis was good $\left(\mathrm{R}^{2}=95,7 \%\right)$ and stress (S) represent goodness of fit $(13,1 \%<25 \%)$. Statistically, RapSubDAS-AMANDIT can be used as rapid quantitative methods to evaluate the sustainability status in management of Amandit sub-watershed. In order to identify the mistake in MDS using RapSubDAS-AMANDIT, the comparison of the result of MDS and Monte Carlo methods in confidence interval $95 \%$ was given in Table 9.

Table 9. The comparison of multidimensional sustainability indices and MDS and Monte Carlo with confidence interval 95\%

\begin{tabular}{|l|l|l|l|l|}
\hline Area within Amandit sub watershed & MDS & Monte Carlo & Difference & Decisions \\
\hline Upstream area & 47,62 & 47,64 & 0,01 & Stable \\
\hline Middle area & 53,17 & 53,24 & 0,07 & Stable \\
\hline Downstream area & 49,25 & 49,39 & 0,14 & Stable \\
\hline
\end{tabular}

Based on the Table 9. It is clear that RapSubDAS-AMANDIT can be used to estimate sustainability status of Amandit sub watershed management integrally. The summary of all calculation regarding integrated management of Amandit sub-watershed was given in Fig. 8.

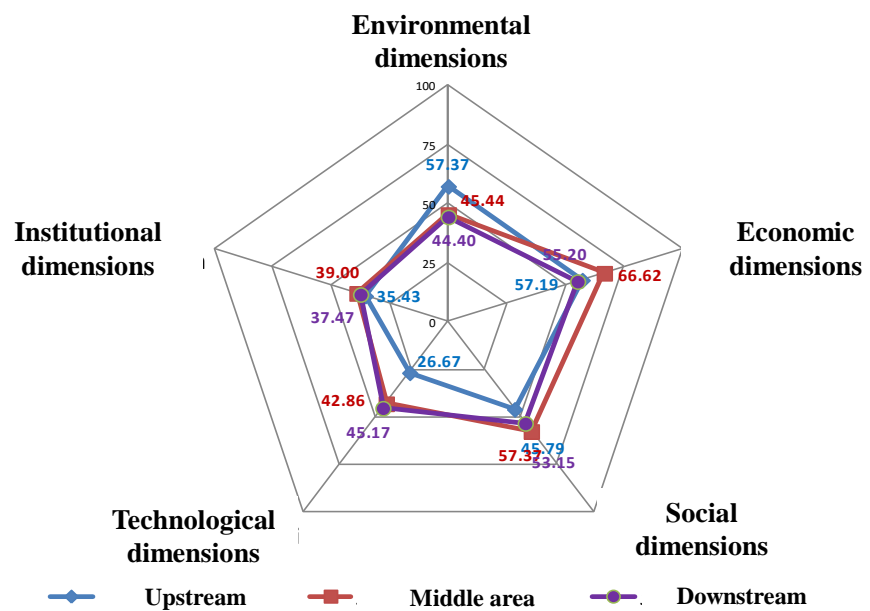

Fig. 8. Kite diagrams shows the status of sub-watershed management sustainability in Amandit sub-watershed in South Kalimantan

In the upstream area, the sustainability of environmental dimension can be classified as moderate (57.37), the sustainability of economic dimension as moderate (57.19), the sustainability of social dimension is poor (45.79), the sustainability of technological dimension is poor (26.67), and the sustainability of institution dimensions is poor (35.43). In the middle area the sustainability of environmental dimension can be classified as poor (45.44), the sustainability of economic dimension as moderate (66.62), the sustainability of social dimension is moderate (57.37), the sustainability of technological dimension is poor (42.86), and the sustainability of institution dimensions is poor (39.00). In the downstream area, the sustainability of environmental dimension can be classified as poor (44.40), the sustainability of economic dimension as moderate (55.20), the sustainability of social dimension is moderate (53.15), the sustainability of technological dimension is poor (45.17), and the sustainability of institution dimensions is poor (37.47). There are, however, important to integrate indigenous knowledge and system of local people in watershed area. It is especially important in Kalimantan because many communities still conserve biodiversity in particular areas, such as home garden. Strengthening home gardens roles and functions as one of the green space area will contributes significantly in watershed sustainability [21]. 


\section{Conclusion}

The sustainability status of Amandit sub-watershed in the dimension of environmental in upstream can be classified as moderate, while in the middle and upstream area were poor. Economical sustainability in all area can be classified moderates. Social dimension of Amandit sub-watershed in upstream can be classified poor, while in the middle and upstream were moderate. The sustainability and institution in all sites can be classified as poor. Overall, the sustainability of Amandit sub watershed was poor. The improvement of watershed management was crucial. Based on the research, the sensitive attributes of all dimension should be prioritized to be improved. It is especially important to meet sustainable resources utilization and management in Amandit sub-watershed area.

\section{References}

[1]. R.J. Reimold, Watershed management: practice, policies and coordination (McGraw-Hill Book Company Europe, 1998).

[2]. A. Bleau, and L.J. Leon. Watershed-based segmentation and region merging. Computer Vision and Image Understanding 77(3), 2000, 317-370.

[3]. P. Roni and Ed Quimby, Monitoring stream and watershed restoration (CABI, 2005).

[4]. V.P. Singh and D.K. Frevert, Watershed models (CRC Press, 2005).

[5]. P.A. Story and D.R. Forsyth, Watershed conservation and preservation: Environmental engagement as helping behavior, Journal of Environmental Psychology 28(4), 2008, 305-317.

[6]. F. Berkes, Common property resources: ecology and community-based sustainable development (Belhaven Press, 1989).

[7]. P.K. Rao, Sustainable development: economics and policy (Blackwell Publishers, 2000).

[8]. S. Bass and B. Dalal-Clayton. Sustainable development strategies: a resource book (Routledge, 2012).

[9]. J. Sayer, and B.M. Campbell. The science of sustainable development: local livelihoods and the global environment (Cambridge University Press, 2004).

[10]. M.S. Grindle and M.E. Hilderbrand. Building sustainable capacity in the public sector: what can be done?. Public Administration and Development, 15(5), 1995, 441-463.

[11]. RT. Koesnandar and H. Sigit. Kajian Degradasi Lahan dan Air di Daerah Aliran Sungai Sengata, Kalimantan Timur (Institute Pertanian Bogor, 2007).

[12]. P. Blaikie and Harold Brookfield, Land degradation and society (Routledge, 2015).

[13]. Badan Pengelolaan Daerah Aliaran Sungai (DAS) Barito. Tata Guna Lahan DAS Barito, (BP-DAS Barito, 2013).

[14]. Peraturan Pemerintah Republik Indonesia Nomor 82 tahun 2001 tentang Pengelolaan Kualitas Air dan Pengendalian Pencemaran Air.

[15]. P. Kavanagh, RAPFISH Software Description (for Microsoft Excel). Rapid Appraisal for Fisheries (RAPFISH) Project (Fisheries Center University of British Columbia. Vancouver, 2001).

[16]. P. Kavanagh and T.J. Pitcher. Implementing Microsoft Excel Software for Rapfish : A Technique for The Rapid Appraisal of Fisheries Status (University of British Columbia. Fisheries Centre Research Reports, 2004).

[17]. T. Dunne, Sediment yield and land use in tropical catchments." Journal of hydrology 42(3), 1979, 281-300.

[18]. C.F. Valentin, R.A. Agus, A. Boosaner, B. Jean-Pierre, C. Vincent T. De Guzman, Runoff and sediment losses from 27 upland catchments in Southeast Asia: Impact of rapid land use changes and conservation practices. Agriculture, Ecosystems \& Environment 128 (4), 2008, 225-238.

[19]. D.I. Stern, M.S. Common, and E.B. Barbier. Economic growth and environmental degradation: the environmental Kuznets curve and sustainable development." World development 24(7), 1996, 1151-1160.

[20]. E. Nkonya, J. Pender, C. Kaizzi, K.Edward, and S. Mugarura. Policy Options for Increasing Crop Productivity and Reducing Soil Nutrient Depletion and Poverty in Uganda. (Intl Food Policy Res Inst, 2005).

[21]. Rahu, A.A, K. Hidayat, M. Ariyadi, and L. Hakim. Management of Kaleka (traditional gardens) in Dayak community in Kapuas, Central Kalimantan. International Journal of Science and Research 3(3), 2014, 205-210. 